DOI: $10.1515 / \mathrm{abcsj}-2014-0026$

\title{
Lacan Frames Scorsese's Paintings in The Age of Innocence
}

\author{
PAULA ANCA FARCA
}

Colorado School of Mines

\begin{abstract}
This article, which brings together film, psychoanalysis, literature, and art, focuses on the role of paintings in Martin Scorsese's The Age of Innocence (1993). Scorsese conveys the imprisonment of New York aristocrats within the framework of social conventions and their evasions of social restrictions through his employment of paintings. Because the protagonists' emotions are not revealed often, the director communicates their dramas and actions with the help of the paintings they own or appear next to. The paintings operate as Jacques Lacan's Other, an entity that watches over the characters to make sure they conform to its selfperpetuating rules. Scorsese's use of paintings shows that the characters perform for the Other and seek to maintain the status quo. While most characters perform within a Lacanian symbolic order, their different responses to a variety of paintings underscore the flexibility of the symbolic order.
\end{abstract}

Keywords: Martin Scorsese, Jacques Lacan, Edith Wharton, The Age of Innocence, adaptation, the Other, symbolic order, gaze, paintings, performance, desire

A proliferation of contemporary literary adaptations during the 1990s suggests the directors' interest in representing the past in innovative and unconventional fashions. While retaining the subtleties of their analogous literary texts, films such as Orlando (Sally Potter, 1992), The Piano (Jane Campion, 1993), The Age of Innocence (Martin Scorsese, 1993), La Reine Margot (Patrice Chéreau, 1994), The Portrait of a Lady (Jane Campion, 1996), and House of Mirth (Terence Davies, 2000) also offer challenging takes on these well-known literary texts. While narrative mimesis remains the privileged means of rendering literary texts in cinema, contemporary 
adaptations do not replicate their intertexts, but engage them in productive rewritings.

In his adaptation, Martin Scorsese tried to preserve the zest of Edith Wharton's 1920 Pulitzer Prize-winning novel which got its title from the painting The Age of Innocence by Joshua Reynolds. Both the novel and the film focus on a love story prevented by the strict social rules of 1870 aristocratic New York. Scorsese conveys the characters' imprisonment within the framework of social conventions and their evasions of social restrictions through his employment of paintings. In an interview with Gavin Smith, Scorsese argues that the paintings of the film transmit certain messages to their viewers: "Paintings were so important . . . if you keep looking at the painting, you notice more things and it tells a story, it tells a way of life" (218). Because the characters' emotions are kept private, the director communicates their dramas, actions, performances, and social affiliations through the paintings they own, admire, or appear next to. Although for the most part, the paintings allude to rigid societal conventions and their followers, they also underscore some of the characters' nonconformity. The solemn portraits hung in majestic rooms operate as Jacques Lacan's Other, an entity that watches over the characters to make sure they conform to its self-perpetuating rules. The Other does not refer to the other person, but to the origin of the symbolic order, language, and law that particularize each subject. For instance, May Welland (Winona Ryder) performs in front of paintings and, because she follows the rules of the Other, she herself becomes a painting. ${ }^{1}$ Her husband, Newland Archer (Daniel Day-Lewis), attempts imaginary identifications through paintings/ mirrors, yet finds himself anchored in the symbolic order.

The performances of the characters in The Age of Innocence are not directed to anybody in particular; these characters do not perform for each other. Instead, Scorsese's use of paintings demonstrates that their performances, meant to ensure them a more comfortable place in society, are for the Other. While most of the characters perform within a Lacanian symbolic order, their different responses to a variety of paintings underscore the flexibility of the symbolic order. The end of the film also adds a temporal dimension to Lacan's symbolic order and emphasizes its 
significant change over the years. Archer's son shows that the social etiquette in his symbolic order differs from his father's, who remains frozen in his, a detail which indicates a historically-layered symbolic order.

For Lacan, the mirror stage represents a fundamental moment in the structure of subjectivity and the formation of the ego. The idealized image in the mirror of the child, source of further identifications, produces a contrast with his fragmented and uncoordinated body. The complete, unified, and, more importantly, illusionary specular image triggers a quixotic quest for an unattainable goal. Understanding that he cannot reconcile the fragmented image with the unified one, the subject realizes he is split. The symbolic dimension follows the mirror stage and refers to the child's connection to language. After the moment of jubilation, the child turns his head to the big Other, the adult (possibly the mother), and asks her to acknowledge the image in the mirror. The Father, the symbol of authority, blocks the child's free access to the mother and lays down the law through language. This interdiction does not refer only to mothers; in The Age of Innocence, for instance, the societal rules interdict the love between Ellen Olenska (Michelle Pfeiffer) and Newland Archer because he is engaged and she is his fiancée's cousin.

While the symbolic order is the realm of language and law, it also encompasses the Other, a Lacanian concept that is difficult to define, yet significant to the subject's entire life and development under the symbolic order and, in this case, to Scorsese's use of paintings. The Other transcends the otherness of the imaginary and the mirror stage because it resists identification. Instead, the Other represents the symbolic order and becomes the site where speech occurs: "the Other must first of all be considered a locus, the locus in which speech is constituted" (Psychoses 274). The subject has to learn from scratch the speech and law of the Other when he enters the symbolic world; during this learning process, the subject is shaped by the rules of the Other. A short comparison between Archer and Beaufort reveals how the rules of the Other influence the subject(s). While Archer belongs to an old family of gentlemen and aristocrats, Beaufort only passes as a gentleman because he climbs the social ladder through his intrepid business flair. Although the film does 
not deal with these two men's upbringing, their different attitudes vis à vis conformity to social etiquettes uncover their association with different families of the Other.

Although Lacan posits that "the Other . . . is already there" (Four Fundamental Concepts 130), the Other loses its meaning and function if the subject is absent. For instance, the Other without a subject is like a theater stage with no actors. The subject personalizes the Other and makes it present and active. Out of all the signifiers from the chain of signifiers, only those significant to a subject will constitute the Other. The subject could select his own group of the Other. In the film, Regina Beaufort marries a rich businessman who is not an aristocrat; by accepting this new social position, she changes both her chain of signifiers and her husband's. When Regina Beaufort asks Mrs. Mingott to use her influence and save Julius Beaufort's honor, the matriarch refuses: "'But my name, Auntie. My name's Regina Townsend.' And I [Mrs. Mingott] said, 'Your name was Beaufort when he covered you with jewels, and it's got to stay Beaufort now that he's covered you with shame"' (The Age of Innocence). Clearly, Regina chose to belong to a category of the Other different from her family's. Scorsese neither introduces nor describes the historical lineage of families such as Townsend or Beaufort; these families function as a historical system that perpetuates itself and enforces rules and laws even when the Other is absent or, as Lacan would say, inexistent.

Lacan writes a whole chapter on pictures in his study The Four Fundamental Concepts of Psycho-Analysis, a chapter which could explain Scorsese's use of paintings in his film and the subjects who gaze at them. While the subject gazes at a painting, the painting gazes back at the subject. Thus, the self-reflexive qualities of the gaze place viewers under scrutiny as well. Because the objects or the subjects of the gaze return the gaze, viewers become conscious of their own active contribution to what they see. They look back at what they have seen, accept their role as viewers, and place themselves and the object of their gaze on display. The paintings that Scorsese chose to depict allude to a certain order, the symbolic order in Lacanian terms, which they impose on the viewers through their gaze. Thus, the Other represented in some of the paintings from The Age of Innocence does not remain an inert Other or a set of 
rigorous symbolic rules that wait for a subject to follow them, but it becomes an active entity. Whereas this fluid entity imposes a set of rules, its gaze also supervises that these rules are obeyed by the viewers. In this way, the paintings stand both as the law and as law enforcers.

Other critics who have analyzed the role of painting in film such as Brigitte Peucker and Angela Dalle Vacche have explored connections between film and art. Examining film against its rival arts like painting and literature, Peucker focuses on the human body, one fragmented by close-ups to the extent to which the film itself becomes a "fissured text [that] brings with it an underlying fear of castration and of death" (4). Dalle Vacche contends that intertextuality and borrowing images from art history function in two ways: "either film is plagued by a cultural inferiority complex and therefore obsessively cites other art forms, or it is self-confident enough to move beyond this state of dependency and arrive at the point where it can teach something new to art historians" (3). I hope to prove that the paintings in The Age of Innocence achieve the latter of Dalle Vacche's predictions. Not only do the paintings Scorsese uses or "borrows" from Wharton's novel reveal the intricate rules of New York aristocracy, but they also guide its owners or viewers into following these strict rules. Thus, the paintings become texts open to interpretation, and, at the same time provide contexts in which viewers understand certain characters and their relationships with New York society.

The paintings represent a medium which immortalizes the societal rules of the Other for the subjects who have to obey them. The film emphasizes different sets of paintings present in various New York households and associates them with different characters who follow the rules of the Other to a greater or lesser extent. New York aristocrats, whose houses abound in family portraits, are more likely to reinforce old rules and traditions; conversely, those households with more modern art apply the rules of the Other more loosely. In many respects, the Other resembles a script that guides the acts of performers such as Ellen, May, and Newland. Ellen understands that New York society accepts her only if she changes her performance to fit the New York elite Other; her endeavor to renounce her independent way of living and the paintings on her walls eventually fails. On the other hand, May's performance vis à vis 
the script is consummate so that she becomes the script. Her framed photo that shows her shooting with a bow and arrow and her hands modeled in Paris dominate the Archers' living room and dictate her rules over the years. However, Newland's conflict revolves around his desperate attempts to see himself as a whole in the mirror, an ideal possible only with Ellen's help, or to adhere to traditional rules. Although he cares "immensely" about paintings, his performance does not escape the conventions put forth in most of the paintings from New York households. Interestingly, at the end of the film and after May's performance and death, Scorsese chooses different paintings for Archer and rearranges the pieces of furniture in his house to suggest that the symbolic order of old New York is alterable in time and susceptible to modification. Nevertheless, old New Yorkers like Newland cannot adapt to a new set of rules - that, for example, his son Ted sets forth - and remain frozen into their adopted symbolic order.

Scorsese underlines the obsessive presence of the Other through portraits that dominate the majority of the scenes with Archer at the beginning of the film. Archer becomes more dignified in rooms with portraits on walls because social etiquette and the inquisitorial gaze of the Other require appropriate conduct. Whenever Scorsese places Archer outside portraits and rigid rules namely, in scenes where Ellen Olenska is present as well, he moves and speaks more freely and naturally because he tries to find himself as a whole. His alienation and sense of estrangement disappear when Ellen accompanies him.

When gentlemen, such as fellow lawyers or New York aristocrats, accompany Archer, his behavior vis à vis societal rules is impeccable. In these situations, Scorsese shows Archer in drawing rooms, libraries, and offices with many portraits of serious men and women who gaze gravely at him. The room where Newland, Mrs. Archer, Janey, and Mr. Sillerton Jackson dine is full of framed portraits of the Archer family ancestors on the wall; the men and women in the portraits gaze suspiciously at the people sitting at the table as if checking them out. Scorsese adds another frame to the characters sitting at the table to suggest their imprisonment in their own world and their incapacity to get out of the rules of the Other; each character is framed by two candlesticks that delineate the space 
where the characters can move. By suggesting the characters' transformation into paintings, Scorsese emphasizes their response and obedience to the Other. The paintings in van der Luydens' drawing room also allude to the characters' metamorphoses into paintings. When Newland and his mother go to the van der Luydens and ask them to save Madame Olenska's honor, Scorsese shows a white wall with portraits of women against which Henry and Louisa van der Luyden sit with looks of frozen gentleness. Their posture, language, and paintings suggest that they will support Ellen only if she behaves or resembles the women in these paintings. Henry offers his help because "as long as a member of a wellknown family is backed by that family, it should be considered final" (The Age of Innocence). If Ellen conforms to the rules of the Other, then she will belong to the New York aristocracy.

Although they belong to New York aristocracy, Julius and Regina Beaufort are often the focus of vicious gossip. Their household, shown in detail because they host the well-known annual ball, represents an intriguing combination between tradition and modernity. Some of the portraits allude to Regina and her old family, while more daring paintings point to Julius and his mysterious affairs. The ballroom scene immediately following the opera scene, which opens the film, abounds in paintings and mirrors that reflect, depict, and multiply the conventions of the New York society and create a "strong sense of the characters' imprisonment" (Pizzello 40). Belén Vidal Villasur argues that the paintings in this scene cancel out the idea of the original when they absorb this original and produce "culturally coded reflections" ("Classic Adaptations" 11). The idea of the original is also cancelled by the doubling effect between the New York aristocrats and the characters in the paintings. The similarities between the content of the paintings and the positions of the guests at the ball suggest the conformity of the New York society to the unwritten yet prevalent rules of the Other.

The camera first shows a huge ornately-framed portrait of Regina Beaufort and then moves to Regina herself, who stands in front of the painting and greets her guests. Since Regina's portrait is the first painting he showed in direct relation to its flesh and blood correspondent, Scorsese underscores the direct connection between the paintings and the 
characters. Several other paintings point to the similarity or, in some cases, the exactness between the movements, positions, and actions of the New Yorkers and the characters in the paintings. For instance, one painting depicts waltzing couples in a ballroom and a group of young women on a couch, a situation that corresponds to Scorsese's arrangement of his characters. In other cases, the voiceover links members of the New York society to paintings. When the voiceover contends that the harmony of this world is so precarious that it "could be shattered by a whisper" (The Age of Innocence), the camera pans on a painting with two men in a crowd whispering presumably about the woman standing next to them. The copies of the gentlemen in the painting, possibly Lawrence Lefferts and Old Mr. Sillerton Jackson, ruin Madame Olenska's reputation with such whispers. Lefferts' reflection is seen in the mirror along with the circling movements of the dancers; the painting next to the mirror also renders lively dancers at a ball. Putting the dancers in the painting with the real dancers reflected in the mirror on the same wall, Scorsese suggests that New Yorkers both imitate the paintings or became paintings themselves. The voiceover explains Lefferts' insistence on details, rules, and form at the expense of content: "[Lefferts] was the foremost authority on form in New York. On the question of pumps versus patent-leather Oxfords, his authority had never been disputed" (The Age of Innocence).

While in the opera scene Scorsese links the New York spectators with the opera performance on the stage, he also insists on the continuation of performance from the opera house to the ball to underscore that New York aristocrats base their lives on public appearances and performances for the Other. The orchestra, the dancers, and the other guests at the ball perform for the Other by complying with the rules imposed by the paintings. Paired up dancers come toward the camera keeping a certain rhythm which represents the strict rhythm of this society. The same sense of rhythm, order, and discipline dominates their dance in the crane shot that closes the ballroom scene. The only one who disrupts the dancers' cadence and their symmetrical rotation is Julius Beaufort, a controversial personage who does not fit within this community of the Other. Scorsese has him walk in slow motion among the dancing couples to underscore his unconventionality and connects the 
lack of symmetry created by his appearance with his disobeying of rules: "Now Julius Beaufort's secret was the way he carried things off. He could arrive casually at his own party as if he were another guest . . . Beaufort was intrepid in his business but in his personal affairs absolutely audacious" (The Age of Innocence). Beaufort's intentional disruption of New York's symmetries reveals his disobeying of rigid rules. Archer, on the other hand, performs his obeying of tradition; he admires silently Bouguereau's nude that Beaufort exhibited audaciously in plain sight, but acts according to the rules that the other paintings impose: "Archer enjoyed such challenges to convention. He questioned conformity in private, but in public he upheld family and tradition" (The Age of Innocence). May and Newland eventually join the waltzing couples and follow their rhythm to show that they conform to the rules of the New York elite.

Another set of paintings that deserve attention are found in the house of Mrs. Mingott, the matriarch of New York. She lives in a large house "of controversial pale cream-colored stone, in an accessible wilderness near the Central Park" (The Age of Innocence) in which she assembled both conventional and modern objects and paintings. Interestingly, Scorsese first emphasizes Mrs. Mingott's more traditional paintings and portraits, while the voiceover explains her role in May and Newland's engagement and future marriage. However, in anticipation of Ellen's arrival to her grandmother's house, the director focuses on more intriguing paintings. Villasur argues that during this required betrothal visit, Newland "gets relegated to a marginal position in the first part of the scene, the main axis of action taking place between the two women and the ring" (Textures of the Image 58). Newland indeed remains in a corner of a room while May, Mrs. Welland, and Mrs. Mingott discuss all the details of the engagement and prospective wedding. The position of May and her mother facing Mrs. Mingott, who sits with several dogs on her lap, and with their back to a portrait of the matriarch, again accompanied by dogs, suggests that they are constrained to apply the rules of the Other as far as marriage goes. According to unwritten New York rules that do not favor long engagements, Mrs. Mingott decides to advance the date of marriage even though Mrs. Welland does not approve. 
While Mrs. Mingott's portrait is linked to more rigid rules, some of her paintings (especially those outside of her drawing room that are somewhat hidden from the eyes of formal guests) are more daring. The variety of her paintings marks the difference between Mrs. Mingott's conservative relatives, like May and Mrs. Welland, and her liberal ones, like Ellen and her parents. The camera moves up the stairs past a gallery of framed paintings depicting landscapes that explain Mrs. Mingott's, and later Ellen's, appeal for wilderness and natural environments. The voiceover also remarks on the foreignness of her furniture and paintings that show scenes from French fiction with women and their lovers. The presentation of the last painting, John Vanderlyn's Death of Jane McCrea, is accompanied by the voiceover's ironical comment: "For now she [Mrs. Mingott] was content simply for life and passion to flow northward to her door and to anticipate eagerly the union of Newland Archer with her granddaughter May. In them, two of New York's best families would finally and momentously be joined" (The Age of Innocence). Vanderlyn's painting that depicts a violent scene from the 1777 Revolutionary War with a white woman killed by two Native Americans also links May and Newland's marriage to violence; the woman that the two patriarchal New York families "kill" is supposedly Ellen so that the union between May and Newland can move forward. Ironically, the camera moves from this painting to Ellen and Beaufort who just arrived in Mrs. Mingott's drawing room.

While the houses owned by rich New Yorkers mirror their wealth and social status, Madame Olenska's Bohemian house differs greatly from the mansions full of sober paintings; her house also differs from Mrs. Mingott's house which gives an impression of secure wealth and power. Ellen moves into "an odd, little house" (The Age of Innocence) located in an unfashionable part of the city. Ellen's unconventionality is evident in the manner she decorates her house, the foreign books she owns, and her variety of bold paintings. She brings Impressionistic artwork from Europe, which New York considers unusual, and Oriental objects that are too exotic and undecipherable for conventional American standards. Her house is much barer than the rest of the mansions where the 
agglomeration of pieces of furniture, paintings, and mirrors obstruct the characters' freedom of mobility and their personal freedom.

Scorsese shows Ellen Olenska's freedom and different taste with a contrast to May. The van der Luydens' dinner in honor of Countess Olenska ends with a close-up on May's face and Louisa's words: "I think I've never seen May looking lovelier. The Duke thinks her the handsomest woman in the room" (The Age of Innocence). From the closeup on May's stereotypical Victorian beauty, the camera moves on the painting with a faceless woman with a parasol, where the absence of physical beauty and even traits, alludes to a world different from May's. This painting, located in Ellen's house, introduces viewers into the décor of her house and her sophisticated personality. Ellen is painted with her parasol but no physical traits by the artist in Boston Park, which also links this painting to the one in her house. Both faceless women symbolize Ellen who does not gaze obsessively at the viewers as other women do in portraits. The form and subject matter of the second painting Archer sees in Ellen's house is equally unsettling in the intensity of its mood. The painting that stretches horizontally defying any shape or content of the paintings seen thus far depicts the opposition between civilization and wilderness. The camera moves from the left, that is from the portrayal of several villas, to the right, namely to fields and the desert, to suggest a removal from civilized society and a return to a more liberating natural environment. Ellen's other paintings depicting little girls, sketches of women, or exotic landscapes offer other adventurous challenges. The asymmetrical curtains, small slender tables, the Japanese mask, and the small vases with flowers suggest choices and adventures along a warm, cozy, and welcoming house.

Because Ellen's house does not resemble the sobriety of the other New York mansions, the paintings in her house also look different. Her pictorial appearances are faceless (Scorsese does not include a portrait of Ellen in the same fashion he does with May, Regina Beaufort, and Mrs. Mingott). Whether Ellen's pictorial homologues point to her directly (in the painting from Boston) or indirectly (in the paintings that only allude to her), she remains faceless. Her facelessness and resistance to conform to the rules of the Other, rules emphasized by the film's numerous portraits, 
link Ellen to the mirror stage. Scorsese's depiction of her invites Archer to investigate her face to face (like in the mirror) as if to recognize his Ideal-I and identify with her. Both in Boston and at her house, Ellen appears right after Archer scrutinizes her faceless paintings to participate in his moments of happiness. Scorsese shows the jubilation associated to the mirror stage, namely, the subject's feeling of whole constituted from all the fragmented parts, with scenes where Archer venerates Ellen. Archer kisses her hand, leg, neck, shoe, glove, or umbrella as if trying to arrange together her body in one whole piece. Moreover, his love and euphoria at the sight of Ellen's body or its substitutes speak about his jubilatory moment. $^{2}$

Lacan's mirror stage presupposes this moment of jubilation when the Ideal-I is formed in the mirror; the subject and his reversed totalizing image in the mirror lead to jubilation. A reversed image in Newland's mirror (at least from a gender perspective) is Ellen. Scorsese punctuates further this moment of jubilation by placing Newland and Ellen in the center of the frame, silencing the voiceover and sometimes the music, and isolating them from the other members of society. In doing that, Scorsese creates a mirror stage effect as he underscores Archer's and Olenksa's presence on the screen as subject and his own image. Their rendezvous usually take place in rooms or open spaces that do not contain somber portraits present in Mrs. Archer's, van der Luydens', and Letterblair's houses or anything else that may remind them of the Other. Isolating Archer and Ellen on screen from the rest of New York society at the opera or presenting them in enclosed spaces such as the carriage, Scorsese emphasizes Archer's moment of jubilation at his identification with his ideal-I, Olenska. In the second scene at the opera, Scorsese uses lightening to set them apart from the other spectators in the opera booth who remain in darkness. The lovers enjoy these moments of privacy Scorsese provides that are also moments of happiness and jubilation for Newland. Ellen's energetic and lively personality has a benefic effect on Archer who is more relaxed and jocular around her.

The end of the film, however, finds Archer contemplating Ellen's windows thirty years after the symbolic order and the Other took over the idealization of his mirror stage. When the promise of a mirror stage or 
Ideal-I reenactment occurs, Archer returns to a more comfortable symbolic order. The sun's reflections on the glass at Olenska's Parisian apartment, which stings Archer's eyes, triggers a mirror stage with an ideal image of Ellen at the wooden pier where she does turn her head and smiles at him. ${ }^{3}$ Yet, his life with May under the eyes of the Other teaches him to reject Ellen just as his peers did before. Archer is no longer the young man enjoying the "challenges to conformity," but an "oldfashioned" New Yorker (The Age of Innocence). That Archer acts in conformity with the demands of the symbolic order is also reinforced by his behavior vis à vis his object of desire. Desire always entails "the desire for something else" (Écrits 158) because our desire for what we already have is impossible. Archer's desire implies his lack of the object of his desire, Ellen Olenska.

Lacan suggests that the symbolic order, the order imposed by the Other, is already established and the subject has to comply with it and perform accordingly. This means that the aristocracy already follows the rules of the Old New York that have been established for centuries. Yet the film goes a step further to suggest that May does not undermine Newland's performance and his failed stratagems to elope with Ellen, but that she connects to Newland's group of the Other. Associating herself with Newland's community of the Other, May performs the entity which establishes the evolution of Newland's performance. May's performance is most notable because she does not perform for another person directly. Instead, her performance includes her in the set of the norms that Newland sees as the Other. Hence, her performance dominates Newland without being directly oriented toward him. Scorsese shows her performance and connection to the Other in at least two ways: through her relations to different families and their unwritten rules and through the paintings associated with her. First, May manipulates Archer who lobbies for the advancement of their marriage date to influential New York families. Secondly, and more importantly, Scorsese indicates that, like Regina Beaufort and Mrs. Mingott, May herself becomes a portrait - an entity that gazes back at the viewers to make sure they follow the rules. May imitates the model imposed by Mrs. Archer and Newland whose house abounds in portraits of ancestors and ultimately becomes a portrait herself. 
May's performance is noticed from the beginning of the film which not surprisingly starts with a performance at the opera. Hearing Lefferts's and Jackson's wicked comments about Countess Olenska's reputation, Archer joins the opera booth, where the Welland and Mingott families are assembled, to show his support and appreciation for May and Ellen. In other words, his engagement with May already makes him responsible for all the members of her family. Furthermore, Scorsese connects characters with performance to emphasize the pretentiousness of 1870 New York. Although Scorsese does not show any paintings in the opera scene, he introduces viewers into the ceremonious and conventional atmosphere of the performative Old New York. The background of the opening credits shows flower buds of various colors blossoming rapidly - an image that suggests the laconic duration of the age of innocence due to the withering of flowers and people's characters. That flowers symbolize people and especially women is made clear by the soprano with a blonde wig who is picking up a yellow daisy and by May who is holding a bouquet of her favorite flowers, lilies-of-the-valley. Since Scorsese chooses to introduce both the soprano and May through flowers, the implication is that both are performers. The camera pans and dissolves through a series of close-ups on details of the 1870 New York opera clothes and accessories such as flowers, jewelry on necks and wrists, tiaras, high collars, men's cufflinks, and flowing ties. Scorsese suggests that May belongs to this community because the camera focuses on May's bouquet first and then on her dress and face.

Newland Archer also becomes part of this subtle and ironical world of flowers and performances because he, too, is introduced by a close-up on the artificial gardenia at his pocket-handkerchief, which underscores his connection to Old New York's traditions. Archer's gestures also betray his dependence on women and their performances. Scorsese shows him twice taking flowers from May at the ball, where they announce their engagement, and from his daughter's wedding bouquet. On both these conventional occasions, Archer supports the institution of marriage and the women who participate in the process of making it possible. Flowers represent both men's conformity to tradition (they offer flowers because they respect and admire women's beauty and propriety) and women's 
performativity (flowers are nonessential but desirable accessories contributing to an effect or result).

Some of May's performances take place behind the scenes, an important detail both in the film and Wharton's novel. May's telegram that informs Ellen about the Welland and Mingott families' decision to advance the wedding date shatters the dreams of her fiancé, Newland, who wants to release himself from his engagement and consume his affair with Ellen. The close-up on Newland's face with his disappointed and awry look and teary eyes dissolves into an upside down mirror of May in her wedding dress, a corrected image of May reflected into the lens of the camera, a still image of May posing in an artificial setting of a photo studio, then multiplied into several replica images in the three mirrors of the studio. The photographer, impersonated by Martin Scorsese himself, immortalizes May's stereotypical poses of Victorian femininity that become paintings in her own house. May's various representations in this sequence point to her elusive personality and "her increasing power and Newland's lack of ability to 'read' her" (Lukas). Newland waits in a corner of the studio and watches May's silent performance; he does not participate at the photo shooting and seems absent to the spectacle of his own marriage. On her wedding day, May becomes a portrait herself that she puts in the drawing room next to Archer's important familial portraits.

May, thus, gets married with Newland, which implies a triumph over her cousin, Ellen. Her victory is rendered through the tiger symbolism at Olenska's house and the photo studio scene. The Fernard Khnopff painting in Ellen's living room, where Archer declares his love for the first time, depicts a tigress with a female head next to a male bust; the tiger represents Ellen's sophistication, elegance, and bohemianism. At the same time, the painting alludes to the physical incompatibility between the two lovers because of their affiliation to different species. The painting does not depict their human bodies as wholes (the tigress has only a human head and the man's body is not entirely shown), which makes their connection to the idealization of the mirror stage impossible. Scorsese explores further the lovers' incompatibility in his rendering of a dead tiger on the floor. The skin of the tiger, where Newland kisses Ellen's shoe, alludes to the futility and termination of their affair. 
Ironically, in the photo studio scene that follows Newland's love declaration, May stands on a tiger skin and assumes the victor's position over her prey, Ellen Olenska.

Scorsese depicts Newland's and May's European honeymoon primarily through paintings and postcards that occupy the whole screen to suggest the characters' conventionality and lack of freedom. The newlyweds become stereotypical personages in paintings that render familiar places; although the paintings and postcards often do not include May and Newland, the implication is that they behave according to the rules prescribed by these visual texts. The voiceover explains that their conformist honeymoon follows the expected trajectory of any rich American couple: "They traveled to the expected places which May had never seen. In London, Archer ordered his clothes, and they went to the National Gallery, and sometimes to the theater ... . In Paris, she ordered her clothes ... . They visited the Tuileries" (The Age of Innocence). Scorsese shows an old postcard with nineteenth-century London followed by another one with Londoners in high hats and long dresses enjoying their walks in the city; Newland and May adopt the English fashion and customs ad literam. The Parisian postcards describing the city and its elegant flâneurs also summarize May's and Newland's activities and dress code. Reiterating Mrs. Mingott's gesture, May has her hands modeled in marble at the sculptor Roché's studio and then displays them in her house; now she can have both eyes and hands on Newland. The lavish honeymoon saga ends with May's control over Newland's desires and freedoms. After she convinces Newland in the carriage not to invite a charming Frenchman to dinner, the voiceover stresses out that "May's pressure was already wearing down the very roughness he most wanted to keep" (The Age of Innocence). As the camera focuses on the newlyweds in the carriage, a black screen surrounds the couple covering more and more of the field of view until it takes over the whole frame. The closing of the frame symbolizes that May closes all of Newland's options and possibilities of his escape from this traditional marriage.

The third scene at the opera, where May wears her wedding dress, also marks her consummate performance. As Margaret sings the same aria from Faust and picks up a daisy, the camera looks down on May from 
above and focuses on her dress; the voiceover explains that "It was the custom, in old New York, for brides to appear in their wedding dress during the first year or two of marriage. But May ... had not worn her bridal satin until this evening" (The Age of Innocence). May wears her wedding dress on this particular evening because she marries Archer for the second time; at the opera, she celebrates her pregnancy and her victory over Ellen Olenska. May subverts the patriarchal order by applying and respecting the patriarchal rules and values; dressed as a bride, she blackmails Archer and Ellen with her pregnancy. Although May's dress is altered by time and her soon-to-be pregnant figure, it represents conventionality and commitment - two values that patriarchy cherishes. Miming conventionality, May disrupts it and becomes unconventional. Villasur points out that May's wedding dress is an impossible symbol in itself: "As a marker both of virginity and of May's status as a newly married woman, the bridal satin reveals the contradictory construction of the female body in the Victorian society" (Textures 86). Her white dress becomes a symbol whose meaning is arbitrary; May's unreadability and whiteness stand for the literal signifier of the blankness her body and dress deliver.

When Ellen leaves, Newland becomes aware of May's performance and of her connection to the community of the Other. Acting in accordance with New York's conventions concerning marriage, May wants Newland to choose between her and his mistress. This choice calls to mind the example Lacan gives, which undermines the subject's choices: "Your money or your life! If I choose money, I lose both. If I choose life, I have life without the money, namely a life deprived of something" (Four Fundamental Concepts 212). Choosing a life deprived of love, Newland feels alienated and lonely. Interpreting Lacan's sentence, Paul Verhaeghe argues that the subject is divided "between the necessary loss of its own being on the one hand and the ever alienating meaning in the Other on the other hand" (176). Choosing the Other, the result "will be an ever more clear delineation of this loss" (Verhaeghe 176).

After it becomes clear that Newland cannot join Ellen in Europe, Scorsese depicts his life under the symbolic order and the gaze of the 
Other. The camera pans slowly around the Newland's drawing room showing each portrait, piece of furniture, or home decoration. The focus on May's photo in her archery costume and the marble sculpture of her hands signal her presence in the room and in Newland's life even after her death. A new generation is born in this very room, which relates directly or more loosely to May and Newland's rules. Their son, Theodore, is baptized in their drawing room under the gazes of his family members and of the family portraits, while their daughter, Mary, announces her engagement in this room. Mary follows more closely the rules of the Other and marries "the dullest and most reliable of Larry Lefferts' many sons." Ted, on the other hand, defies the rules of the Other in his family and gets engaged with Julius Beaufort's and Annie Ring's daughter, Annie, whose relatives were the favorite subjects of gossip in Old New York.

As an architect, Ted redecorates the Archers' drawing room and replaces many of the family portraits and the furniture with more modern furnishings. He also offers his father the unique chance to rebuild his life by inviting him to Paris and to Madame Olenska's apartment. All these changes demonstrate that Ted Archer adheres to another community of the Other, different from his parents'. His progressive way of life also underscores the flexibility of the symbolic order which changes along with its signifiers. While his son disregards old traditions, Newland remains anchored in a rigid symbolic order that reinforces May's community of the Other. Like May, whose "world of her youth had fallen into pieces and rebuilt itself," Newland remains an old-fashioned gentleman who is unable to embrace the world's rebuilding. Responding to his community of the Other, he chooses not to visit Madame Olenska.

Like many of the contemporary adaptations, Martin Scorsese's The Age of Innocence renders and intensifies the subtleties of its source text, Edith Wharton's 1920 novel. Scorsese's visual adaptation of Old New York aristocracy reveals his insistence on form and décor; he envelops the rapports between characters into rigorous etiquettes, opulent dinners, luxurious furniture, and paintings. Scorsese's use of paintings illuminates the characters' relations to the rules of their society; each New York family owns a different set of paintings through which they impose certain 
guidelines. Thus, the characters perform naturally these rules imposed by a system that perpetuated itself for decades. The film does not show the characters performing for each other, but for another entity that Lacan defines best as the Other. New York aristocrats' performance of conventions dictates the destiny of the protagonists. May Welland imitates patriarchy for the purpose of subverting it; her performance guarantees her the place and role of the dutiful wife in Archer's community of the Other. Archer, on the other hand, renounces the idealizations and jubilations that Ellen promises, in order to join the societal conventions of Old New York. Several further investigations merit critical attention. Analyses of other aspects of the mise-en-scène such as furniture and home decorations also reveal the characters' imprisonment in their world. Moreover, a look into the absentees of the film such as Annie Ring (Beaufort's mistress) and her daughter, Newland's father, May's father, and Ellen's husband would strengthen this society's connections to the rules of the Other.

\section{Notes:}

${ }^{1}$ George Castellitto believes that some of the paintings that depict women, "actually serve to highlight the control that the women in the film either exert or to which they succumb" (26).

${ }^{2}$ Kathy Hadley argues for Newland's blindness and inability to cope with reality and contends that while he "becomes obsessed with Ellen's story, he has almost no curiosity about his wife's" (267).

${ }^{3}$ The static shot of Ellen's silhouette against a glorious sunset, luminous water, golden lighthouse, and passing ship "fuses actual perception with visual convention; the frame itself turns into a canvas" (Villasur, "Classic Adaptations" 12). Thus, Ellen is not going to turn around because Newland wants to preserve her fictional, static image.

\section{Works Cited}

Castellitto, George. "Imagism and Martin Scorsese: Images Suspended and Extended." Literature Film Quarterly 26 (1998): 23-30. Print.

Hadley, Kathy Miller. "Ironic Structure and Untold Stories in The Age of Innocence." Studies in the Novel 2 (1991): 262-72. Print.

Lacan, Jacques. The Psychoses 1955-1956: The Seminar of Jacques Lacan Book III. Ed. Jacques-Alain Miller. Trans. Russell Grigg. New York: Norton, 1993. Print. 
- - -. Écrits: A Selection. Trans. Bruce Fink. New York: Norton, 2002. Print.

- - -. The Four Fundamental Concepts of Psycho-Analysis. London: Hogarth P, 1977. Print.

Lukas, Karli. "Creative Visions: (De)Constructing 'The Beautiful' in Scorsese's The Age of Innocence." Senses of Cinema 25 (2003): n. p. Print.

Peucker, Brigitte. Incorporating Images: Film and the Rival Arts. Princeton: Princeton UP, 1995. Print.

Pizzello, Stephen. "Cinematic Invention Heralds The Age of Innocence." American Cinematographer 74 (1993): 35-45. Print.

Smith, Gavin. "Martin Scorsese Interviewed." Martin Scorsese: Interviews. Ed. Peter Brunette. Jackson: U of Mississippi P, 1999. 200-19. Print.

The Age of Innocence. Dir. Martin Scorsese. Perf. Daniel-Day Lewis, Michelle Pfeiffer, and Winona Ryder. Columbia Pictures, 1993. Film.

Vacche, Angela Dalle. Cinema and Painting: How Art Is Used in Film. Austin: U of Texas P, 1996. Print.

Verhaeghe, Paul. "Causation and Destitution of a Pre-ontological Non-entity: On the Lacanian Subject." Key Concepts of Lacanian Psychoanalysis. Ed. Dany Nobus. New York: Other, 1998. 164-89. Print.

Villasur, Belén Vidal. "Classic Adaptations, Modern Reinventions: Reading the Image in the Contemporary Literary Film." Screen 43 (2002): 5-18. Print.

- - -. Textures of the Image: Rewriting the American Novel in the Contemporary Film Adaptation. Valencia: Biblioteca Javier Coy d'studies nord americans, 2002. Print. 